\title{
SENO GUMIRA AJIDARMA AND FICTIONAL RESISTANCE TO AN AUTHORITARIAN STATE IN 1990S INDONESIA
}

\section{Michael H. Bodden}

During the 1990s, Seno Gumira Ajidarma has emerged as perhaps the preeminent fiction writer of the Indonesian younger generation. He is certainly one of the most productive. Since 1993 he has published six collections of short stories, a highly experimental novel, and a collection of essays on journalism, literature, and politics.

He can also be regarded as one of the more courageous of the younger writers. Many of his works touching on sensitive social and political problems, especially those dealing with East Timor-Saksi Mata (Eye Witness or "Witness of the Eyes"1), and Jazz, Parfum dan Insiden (Jazz, Perfume, and an Incident"2)-were published prior to Suharto's ouster, in an atmosphere in which banning was still very much a possibility, though social pressure and struggle were gradually forcing the government grudgingly to concede more freedom of expression. ${ }^{3}$ Saksi Mata and Jazz, Parfum dan Insiden, in particular, have earned Seno considerable respect among his contemporaries, activists, and the current generation of students. These stories have helped create some

\footnotetext{
1 Seno Gumira Ajidarma, Saksi Mata (Yogyakarta: Yayasan Bentang Budaya, 1994).

2 Seno Gumira Ajidarma, Jazz, Parfum dan Insiden (Yogyakarta: Yayasan Bentang Budaya, 1996).

${ }^{3}$ To indicate the risks involved in publishing on such issues, and as his essay in this issue of Indonesia clarifies, it should be noted that Seno, himself, was sacked from his job as Editor of the news magazine, Jakarta-Jakarta, in early 1992, for allowing the magazine's report on the Dili, Santa Cruz massacre of November 1991 to be published. For more details on this incident, see his introduction to the translation of the Eyewitness collection published in Australia. Seno Gumira Ajidarma, Eyewitness (Sydney: ETT Imprint, 1995).
} 
awareness, among a formerly relatively uninformed national population, of the New Order government's barbarous actions in East Timor. Yet they were not the first works that dealt with government/military violence against Indonesian citizens and residents of territories occupied by Indonesia. His trilogy of short stories about the Petrus killings of 1983-84, originally published in the mid-1980s, then gathered in the collection Penembak Misterius, ${ }^{4}$ gave some indication of Seno's penchant for publicly exposing and condemning government-sponsored violence. A number of his recent writings have extended this commitment. The story, "Clara" is one example, as are his playscript "Mengapa Kau Culik Anak Kami?" (Why Did You Kidnap Our Child?), and a story published in Kompas, "Telpon Dari Aceh" ("Phone Call From Aceh," August 8, 1999).

But Seno is interesting for other reasons as well. His commitment to oppose state violence has been packaged in a number of forms over the past ten years. These forms are fascinating in the way they register several artistic modes of resistance to New Order authoritarianism. Seno's work would seem to be one of the preferred reading materials of Indonesia's emerging middle class, to the extent that they read "art fiction" at all. Seno's books, though not selling as spectacularly as those of Pramoedya Ananta Toer, or even Ayu Utami's recent sensation, Saman, ${ }^{5}$ have nonetheless registered consistently respectable sales when gauged against most modern Indonesian literature. For example, though typical print runs for modern Indonesian literature may be as small as one thousand to five thousand, nonetheless, Saksi Mata (1994) will soon be into its third printing, and Penembak Misterius (1993), Jazz Parfum dan Insiden (1996), and Sebuah Pertanyaan Untuk Cinta $(1996)^{6}$ have all recently seen a second print run. Perhaps more important as an indicator of his growing reputation, Seno's work is in demand, and is published regularly, in several of the largest circulation Indonesian dailies, such as Kompas, Republika, Suara Pembaruan, and Media Indonesia. His work also appears in popular magazines like the now notorious men's magazine, Matra, as well as the children's magazine, Hai, the rather staid literary journal, Horison, and the more avant garde cultural journal published by Goenawan Mohamad and associates, Kalam. Seno's work is literally everywhere. It is in this sense that his works can be considered a register of the middle-class artistic modes of resistance.

The first phase of Seno's fictional production includes some work in a psychological realist vein, but also illustrates his interest in the "magic realist" or absurdist style of writers such as Budi Darma, Danarto, and Putu Wijaya, whose works often masked sharp social criticism in narrative structures that explored to varying degrees dream logic and the irrational in human existence, or which questioned the nature of perception and reality. This period in Seno's career culminated in the early 1990s with the stories about East Timor later gathered in the Saksi Mata collection.

At about the same time he was finishing these stories, he began to experiment with a new style, incorporating elements of western postmodernism: collage, blurring of the boundaries between fact and fiction, abandonment of a unified narrative structure, a fascination with popular culture, conscious foregrounding of the process of writing.

\footnotetext{
${ }^{4}$ Seno Gumira Ajidarma, Penembak Misterius (Jakarta: Pustaka Utama Grafiti, 1993).

5 Ayu Utami, Saman (Jakarta: Kepustakaan Populer Gramedia, 1998).

${ }^{6}$ Seno Gumira Ajidarma, Sebuah Pertanyaan Untuk Cinta (Jakarta: Gramedia, 1996).
} 
Pioneered most prominently by figures such as Afrizal Malna, Budi S. Otong, and Nirwan Dewanto, this avant garde postmodernism could be viewed as yet another mode of resistance to a New Order society presided over by an authoritarian state intent on propagating unitary narratives of Indonesian nation, history, culture, and individual identity. Seno's single novel to date, Jazz, Parfum dan Insiden, illustrates his engagement with this strategy of resistance. In it, he abandons a single, unitary narrative, even those of the Indonesian "magic realists" with their breathtaking reversals of everyday logic and causality. Jazz Parfum dan Insiden is built out of three alternating thematic streams: a series of essays about jazz as an art form, a string of stories about love affairs the narrator has had or heard about from friends, and a final stream following an editor reading through news reports of the Dili, Santa Cruz massacre of November 1991. The three streams show little direct connection, challenging the reader to attempt a synthesis of his/her own. Further, the "Jazz" sections extol jazz as a democratic art form born of the desire for suffering to find a voice. It is also envisioned as a supreme form of art in its foregrounding of improvisation, free play, spontaneity, and surprise. In these ruminations, the narrator is clearly delineating an ideal artistic structure in opposition to several of the key concepts of New Order society, notably its obsessions with securing a certain kind of social orderliness, hierarchy, and centralized control. Yet the brutal reality of the Dili massacre, coupled with the difficulty of speaking the truth directly through the mass media-or in any other form-shines through as the moral fuel that fires Seno's deconstructive attack.

Seno's current phase corresponds in a complicated fashion to the travails of the socalled "Reform" period which Indonesia has been experiencing since Suharto's fall in May 1998. Though still highly interested in experimenting with narrative technique and subjectivity, and in questioning, in postmodern fashion, the nature of an alwayshumanly-mediated truth (as the essay translated in this volume demonstrates), he has begun to write stories and play scripts that seem part of a new impulse toward a sastra aktual or topical literature. This new topical literature may still contain remnants of postmodern disjuncture and irony, or magic realist dream logic, but it tends to focus more directly, in a generally "realist" style, on a variety of social/political issues that were difficult to handle in straight-forward fashion prior to 1998.7 Other examples of such literature might be Putu Oka Sukanta's novel Merajut Harkat ("Weaving Together a Fabric of Dignity" 8 ), a narrative centering on the experiences of a political detainee in the 1960s, and Korrie Layun Rampan's Api, Awan, Asap ("Fire, Cloud, Smoke"9), which deals openly with Dayak land rights and the practices of forest companies in Kalimantan. Though pioneering works for this trend existed prior to May 1998 (most notably Pramoedya"s autobiographical prison notes, Nyanyi Sunyi Seorang Bisu, 1995 $\& 1997,{ }^{10}$ and Ayu Utami's Saman, for example), it seems to be reaching a peak in the

\footnotetext{
${ }^{7}$ In fact, Seno's tendency to tackle topical issues in his fiction, coupled with his interest in popular culture, have earned him a reputation with at least one critic-Budi Darma-as a writer of fiction that erases the boundaries between news report and fiction, commercial art and some more "pure" art.

8 Puta Oka Sukanta, Merajut Harkat (Yogyakarta: Jendela Budaya \& Pustaka Pelajar Yogyakarta, 1999).

${ }^{9}$ Korrie Layun Rampan, Api, Awan, Asap (Jakarta: Grasindo, 1999).

10 Pramoedya Ananta Toer, Nyanyi Sunyi Seorang Bisu 1 (Jakarta: Lentera, 1995), and Nyanyi Sunyi Seorang Bisu 2 (Jakarta: Lentera, 1997).
} 
156 Michael H. Bodden

post-1998 "reform" era in which some fields of cultural production have witnessed a real expansion of freedom of expression, despite threats of a reversal from the Indonesian military and political elite. A number of stories in Seno's most recent collection, Iblis Tidak Pernah Mati,11 including "Clara", and "Jakarta, Suatu Ketika" ("Jakarta, at a Certain Point in Time") are also representative of this emerging direction in contemporary Indonesian fiction.

Yet, it would be misleading to see Seno's work as simply a register of resistance and dissent. For Seno's stylistic peregrinations are also those of an extremely productive and creative cultural worker who is constantly seeking new ways to tell stories, to bring feelings and moments of reality to presence in fiction. One need only read the stories collected in Negeri Kabut ${ }^{12}$ to get a sense of the way in which many of Seno's stories are experiments in expanding the range of ways in which modern Indonesian fiction can convey a broad spectrum of human experiences. Ultimately, the combination of these aspects makes Seno a very exciting writer, one whose efforts in the years to come should be worth watching.

11 Seno Gumira Ajidarma, Iblis Tidak Pernah Mati (Yogyakarta: Galang Press, 1999).

${ }^{12}$ Seno Gumira Ajidarma, Negeri Kabut (Jakarta: Grasindo, 1996). 